\title{
The molecular mechanisms of calcium signalling in Chlamydomonas flagella
}

\author{
PW Collingridge*, G Wheeler, C Brownlee \\ From First International Cilia in Development and Disease Scientific Conference (2012) \\ London, UK. 16-18 May 2012
}

The motile green alga, Chlamydomonas, has long been used as a model system to understand flagella structure and function. In addition to the well characterised roles of cilia and flagella in motility, cell biologists are becoming increasingly aware of their importance as cellular sensors. $\mathrm{Ca} 2+$-dependent signalling mechanisms are associated with many flagellar processes, although in many cases the underlying mechanisms remain unclear. Whilst Chlamydomonas possesses many genetic and biochemical advantages for the study of flagella, imaging $\mathrm{Ca} 2+$ in this alga has proven to be problematic. We have developed techniques to introduce $\mathrm{Ca} 2+$ responsive fluorescent dyes into Chlamydomonas cells via biolistics, which enables us to routinely and robustly image $\mathrm{Ca} 2+$ in both the cytosol and in the flagella. To visualise $\mathrm{Ca} 2+$ elevations within the flagella, we have developed imaging techniques using Total Internal Reflectance Fluorescence (TIRF) microscopy. This approach allows us to specifically image fluorescence from the flagella at high spatial and temporal resolution in the absence of interfering fluorescence from the cell body. We have found that Chlamydomonas flagella exhibit a range of dynamic $\mathrm{Ca} 2+$ elevations in response to different stimuli. Each flagellum demonstrates the ability to generate $\mathrm{Ca} 2+$ elevations independently from each other, suggesting a level of control in Chlamydomonas flagella signalling processes not previously demonstrated. We are currently using RNAi approaches to assess the contribution of different flagella-localised ion channels to these $\mathrm{Ca} 2+$ signalling processes.

Published: 16 November 2012

The Marine Biological Association of the United Kingdom, UK
doi:10.1186/2046-2530-1-S1-P19

Cite this article as: Collingridge et al:: The molecular mechanisms of calcium signalling in Chlamydomonas flagella. Cilia 2012 1(Suppl 1):P19.

Submit your next manuscript to BioMed Central and take full advantage of:

- Convenient online submission

- Thorough peer review

- No space constraints or color figure charges

- Immediate publication on acceptance

- Inclusion in PubMed, CAS, Scopus and Google Scholar

- Research which is freely available for redistribution

\section{() Biomed Central}

(c) 2012 Collingridge et al; licensee BioMed Central Ltd. This is an Open Access article distributed under the terms of the Creative Commons Attribution License (http://creativecommons.org/licenses/by/2.0), which permits unrestricted use, distribution, and reproduction in any medium, provided the original work is properly cited. 